\title{
Market Chain Analysis of Cotton the Case of Arbaminch Zuria District, Gamo Gofa Zone, Ethiopia
}

\author{
Abayneh Feyso Ergetew* \\ Department of Agribusiness and Value Chain Management, Arbaminch University, College of Agricultural Science, Ethiopia
}

Submission: October 27, 2018, Published: November 20, 2018

"Corresponding author: Abayneh Feyso Ergetew, Department of Agribusiness and Value Chain Management, Lecturer at Arbaminch University, College of Agricultural Science, Arbaminch, Ethiopia.

\begin{abstract}
Both primary and secondary data were used. A total of 123 sample households were selected from three kebeles of Arbaminch zuria district and 26 cotton traders, 9 small and micro enterprises, and one textile company were interviewed using semi structured questionnaire. Descriptive statistics and Econometrics models were used to analyze the data. Descriptive statistics results show that the main cotton market chain actors in the study area are input supplier, producers, local collectors, wholesalers, ginners, cottage level weavers, textile factories and retailers. Market concentration ratio at district level was calculated using $\mathrm{HHI}$ and its value was 0.553 , which shows that cotton marketing was highly concentrated on hands of few in the study area.

Econometrics models analysis shows that six variables, namely; cotton farming experience, size of land allocated to cotton in hectare, use of improved seed and current year cotton price were significant at $1 \%$ significance level, whereas number of extensions contact and distance to nearest market were found to be significant at $5 \%$ significance level. Provision of new improved cotton varieties, regulation and implementation of cotton price tariffs, strengthening and provision of sustainable and knowledge-based extension service were recommended to improve and strengthening cotton value chain in the study area.
\end{abstract}

Keywords: Cotton; Market chain; Chain actors; Marketing; Arbaminch zuria

Abbreviations: SNNPRs: Southern Nation's Nationalities and Peoples Regional State; TGMM: Total Gross Marketing Margin; ME: Marketing Efficiency; HHI: Herfindahl-Hirschman Index; GMMLC: Gross Market Margin of Local Collectors; GMMRR: Gross Market Margin of Retailers; GMMWS: Gross Market Margin of Wholesalers; GMMTC: Gross Market Margin of Textile Company; GMMPP: Gross Market Margin of Producers

\section{Introduction}

\section{Background and justification}

Ethiopia is believed to be one of the origins of cotton, and cotton cultivation is deep-rooted in the history of the country's agriculture. It is one of the major cash crops in the country and is extensively grow in the lowlands under large-scale irrigation schemes and also it is grow on small-scale farms under rainfed agriculture. The economic value of cotton in the Ethiopian economy is significant. Firstly, it is a major industrial input for textile firms. The textile and garment industry is one of the priority areas in Ethiopia's industrial policy. Secondly, cotton is a major export crop [1]. However, Ethiopia share only about 5\% of total cotton produced in Africa [2]. As to total arable and potential area for cotton production, the country is utilizing below potential. According to Bosena et al. [3], out of the country's total potential areas for cotton production, only about $4 \%$ is being utilized. As a result, the amount of cotton produced in the country is low. Cotton is grow in many regions in the country. In each region, there are wide potential areas. Gamo Gofa zone is the second largest cotton growing region in the country after the Amhara
Region [4]. However, most studies which have been conducted on cotton marketing [1-3,5] were limited to a specific (Awash Valley, Humera, Metema and Abobo) areas. This study was designed to analyze cotton market chain to generate information about its entire market chain in the study area due to absence of adequate information on cotton market channel, market structure, conduct and performance cotton marketing had been a challenge for the farmers as they were getting low prices from the local middlemen [6]. Having these evidences, cotton market chain analysis is conducted in Arbaminch Zuria District of Gamo Gofa zone with the specific objectives of analyzing cotton market channel, market structure, and conduct performance and to analyze factors affecting market supply of cotton at farm level.

\section{Research Method}

\section{Description of the study area}

Arbaminch zuria district is one of the districts found in Gamo Gofa zone of the Southern Nation's Nationalities and Peoples Regional State (SNNPRs). The District is located at a distance of 275 and $505 \mathrm{~km}$ from the regional city, Hawassa and the country 
capital, Addis Ababa, respectively. The district covers $1001 \mathrm{~km}^{2}$ and has twenty-nine rural kebeles and one District town. Based on 2007 population census, Arbaminch zuria district had a total population of 164,529 of whom 82,199 (49.9\%) are men and $82,330(50.1 \%)$ are women.

The population density of the study area varies from 172 person $/ \mathrm{km}^{2}$ to 2268 person $/ \mathrm{km}^{2}$. The mean monthly maximum and minimum temperature of the study area ranges between $33.8{ }^{\circ} \mathrm{C}$ in February to $28.1{ }^{\circ} \mathrm{C}$ in July and $18.2{ }^{\circ} \mathrm{C}$ in April to 15.3 ${ }^{\circ} \mathrm{C}$ in December. The mean annual total rainfall of the study area is about $963.3 \mathrm{~mm}$ with two rainy seasons. The main rainy season is March, April and May which have 172.35mm and 129.13mm mean monthly rainfall in April and May, respectively. The second highest monthly rainfall is recorded in September and October, $126.6 \mathrm{~mm}$ and $133.05 \mathrm{~mm}$.

\section{Sampling procedures and sample size}

To draw representative cotton producer farmers. In the first stage, three kebeles were selected randomly from ten cotton producer kebeles of the study district. In the second stage, households were selected randomly from complete list of households of selected kebeles and sample size was determined according to formula given by Yamane [7], at 95\% confidence interval with $9 \%$ precision level $(\mathrm{e})=0.09$.

$$
n=\frac{N}{1+N(e)^{2}}=\frac{26931}{1+26931(0.09)^{2}}=122.89 \approx 123
$$

Where;

$\mathrm{n}$ : sample size for research use, N: total number of households of the Arbaminch zuria district and e: designates precision level and ranges from 0.05 to 0.1 .

For this research $\mathrm{e}=0.09$ was taken as precision level. Because according to Meryem [8]. as ' $e$ ' gets approaches to 0.05 the sample size gets larger and larger, as a result it becomes difficult to manage. Sample size for each kebele was distributed based on proportional to size of total households.

Trader survey was held at Kola shelle market places during pick cotton harvesting period since, November 1st to December 30th because marketing held on weekly basis once every Saturday and farmers supply cotton to only Kola shelle market. All local collectors (6 in number), wholesaler (only one in number) and retailers (19 in number) were sampled and interviewed.

\section{Methods of data analysis}

Descriptive and econometric data analysis methods were used to analyze the data. Socio-economic and demographic characteristics of market actors and market structure- conductperformance were analyzed using descriptive statistics while econometric model was used to analyze factors affecting quantity of cotton supplied to market.

To identify market structure Hirschman Herfindahl index was used to measure degree of market concentration to characterize market structure. HHI was used because unlike the four-firm concentration ratio, it reflects both the distribution of the market shares of the top four firms and the composition of the market outside the top four firms. It also gives proportionately greater weight to the market shares of the larger firms, in accord with their relative importance in competitive interactions [9]. Market concentration is a function of the number of firms in a market and their respective market shares. $\mathrm{HHI}$ is calculated as:

$$
H H I=\sum_{i=1}^{n} M S_{i}^{2}
$$

Where;

MSi: Is the Market Share of seller i; and n: Is the number of sellers in the market. The market shares were calculated based on quantities of cotton handled by each seller as follows:

$$
M S i=\frac{V i}{\sum_{i=1}^{n} V i}
$$

Where;

$\mathrm{V}_{i}$ : is the quantity of cotton handled by $\mathrm{i}^{\text {th }}$ seller (in $\mathrm{kg}$ ); and $\Sigma \mathrm{VI}$ is the total quantity of cotton handled by sellers in the market (in $\mathrm{kg}$ ).

To measures of the performance of cotton marketing system marketing margin and marketing efficiency were used. Marketing margin is defined as the difference between the price the consumers pay and the price the producers receive. Computing the total gross marketing margin (TGMM) is always related to the final price paid by the end consumer, expressed in percentage [10].

$$
T G M M=\frac{P c-P p}{P c} \times 100
$$

Where;

TGMM=total marketing margin; $\mathrm{Pc}=$ consumer price; $\mathrm{Pp}$ $=$ producer price.

Also marketing efficiency was analyzed to measure either cotton marketing was efficient or not. Marketing efficiency is defined as the ratio between net marketing returns and marketing costs expressed as a percentage. According to Osougwu [11], marketing efficiency (ME) ratio ranges from zero (0) to infinity. A ratio of $100 \%$ shows that the market is perfectly efficient because price increment is just high enough to cover the cost of marketing commodities.

$$
\mathrm{ME}=\frac{\text { output of marketing }}{\text { input of marketing }} \times 100
$$

Multiple Linear Regression model was used to analyze factors affecting farm level cotton supply in Arbaminch zuria district. According to Gujarati [12], model specification of supply function in matrix notation was specified as:

$$
Y_{i}=\beta_{o}+\beta_{i} X_{i}+U_{i}
$$


Where;

$\mathrm{Yi}=$ quantity cotton supplied to the market $(\mathrm{Kg} /$ house hold/ year), $\beta_{o}$ : is constant term, a vector of estimated coefficient of the explanatory variables, $X_{i}$ : a vector of explanatory variables, : disturbance term.

\section{Result and Discussion}

\section{Socio-economic characteristics of sampled households}

The survey result in (Table 1) below shows that mean age of the sample households head was 50.7 years whereas average cotton farming experience of sampled cotton producer farmers was 27.61 years. It is believed that household heads with long years of experience benefits from cotton production decision making and risk taking.

Table 1: Socioeconomic characteristics of sampled household.

\begin{tabular}{|c|c|c|c|c|c|}
\hline Variables & $\mathbf{n}$ & $\begin{array}{c}\text { Mini- } \\
\text { mum }\end{array}$ & $\begin{array}{c}\text { Maxi- } \\
\text { mum }\end{array}$ & Mean & $\begin{array}{c}\text { Std. Devia- } \\
\text { tion }\end{array}$ \\
\hline $\begin{array}{c}\text { Age of Sampled } \\
\text { Household Head }\end{array}$ & 123 & 26 & 82 & 50.7 & 12.98 \\
\hline $\begin{array}{c}\text { Experience of } \\
\text { Cotton Farming }\end{array}$ & 123 & 4 & 58 & 27.61 & 13.09 \\
\hline Total Family Size & 123 & 5 & 17 & 8.9 & 3.91 \\
\hline $\begin{array}{c}\text { Age Less <14 } \\
\text { Years }\end{array}$ & 123 & 0 & 6 & 1.9 & 1.98 \\
\hline Age 14 -64 Years & 123 & 1 & 16 & 3.9 & 3.34 \\
\hline Age >64 Years & 123 & 0 & 3 & 0.32 & 0.59 \\
\hline
\end{tabular}

Source: Author Computation, 2016

Table 2: Demographic and socio-economic characteristics of sampled traders (categorical).

\begin{tabular}{|c|c|c|c|}
\hline Variables & Indicators & Frequency & Percent \\
\hline \multirow{3}{*}{ Sex of traders } & Male & 14 & 53.8 \\
\cline { 2 - 4 } & Female & 12 & 46.2 \\
\hline \multirow{3}{*}{ Types of trading } & Total & $\mathbf{2 6}$ & $\mathbf{1 0 0}$ \\
\cline { 2 - 4 } & Wholesaler & 1 & 3.8 \\
\cline { 2 - 4 } & Retailers & 19 & 73.1 \\
\hline & Local collectors & 6 & 23.1 \\
\hline \multirow{3}{*}{ Education level } & Total & $\mathbf{2 6}$ & $\mathbf{1 0 0}$ \\
\cline { 2 - 4 } & Grade 1-4 & 17 & 65.4 \\
\cline { 2 - 4 } & Grade 5-8 & 6 & 23.1 \\
\hline \multirow{3}{*}{ License conditions } & Grade 9-10 & 2 & 7.7 \\
\cline { 2 - 4 } & $\mathbf{1 0 + 1 ~ \& ~ a b o v e ~}$ & $\mathbf{1}$ & $\mathbf{3 . 8}$ \\
\cline { 2 - 4 } & Yes & 6 & 23.1 \\
\hline \multirow{2}{*}{ Source of initial capital } & No & 20 & 76.9 \\
\cline { 2 - 4 } & Relatives & 1 & 3.8 \\
\hline \multirow{2}{*}{ Author saving } & 25 & 96.2 \\
\hline
\end{tabular}

Source: Author Computation, 2016

The survey result presented in (Table 1) above shows that mean family size of the total sampled households was 8.9 with average working age family members of 3.9 which was higher than that of dependent age group. Having large family size with working age group might have a positive impact on the volume of cotton production and marketing and also might reduces the extra labor cost incurred for cotton production and marketing.

Survey result presented in the (Table 2) shows that mean age of sampled traders was 38.26 years and $53.8 \%$ of the sample traders were male and $46.2 \%$ were female. Also, survey result shows that among total surveyed traders $73.1 \%$ were retailers, $23.1 \%$ were local collectors and only $3.8 \%$ were wholesalers. The survey result shows that $65.4 \%$ of the surveyed traders has attended grade $1-4$, $23.1 \%$ attended grade $5-8,7.7 \%$ and $3.8 \%$ were attended grade 9-10 and above grade $10+1$, respectively. As depicted in (Table 2) above among surveyed traders, $76.9 \%$ were not licensed and only $23.1 \%$ were licensed. With regard to source of initial capital $96.2 \%$ were started the business with their Author saving.

\section{Cotton marketing channel}

Marketing channel is the sequence of intermediaries through which commodities pass from producer to consumer [13]. This channel may be short or long depending on kind and quality of the product marketed available, marketing services and prevailing social and physical environment. Having such concepts in this part of the paper marketing channels were analyzed to identify the alternative routes through which product flows from the point of origin to final destination. The main marketing channels identified from the point of production until the product reaches to the final consumer were three. Their integration and commodity flow routes described below.

Channel I: Farmers $\rightarrow$ Retailers $\rightarrow$ Local Ginners $\rightarrow$ Handloom Weaver $\rightarrow$ consumers

Table 3: Channel of cotton flow and amount sold.

\begin{tabular}{|c|c|c|c|}
\hline Variables & Indicators & Frequency & Percent \\
\hline \multirow{4}{*}{$\begin{array}{c}\text { To whom do } \\
\text { you sold }\end{array}$} & Retailers & 29 & 23.58 \\
\cline { 2 - 4 } & Local collectors & 64 & 52.03 \\
\cline { 2 - 4 } & Wholesalers & 30 & 24.39 \\
\cline { 2 - 4 } & Total & 123 & 100 \\
\hline
\end{tabular}

\section{Source: Author Computation, 2016}

As indicated in the (Table 3) and (Table 4) above 23.58\% of sampled households sold cotton to retailers and average maximum quantities of cotton supplied from sampled household were $200 \mathrm{~kg}$ and total quantity sold via this channel from sampled house hold were $9.3 \%$.

ChannelII:Farmers $\rightarrow$ LocalCollectors $\rightarrow$ Wholesalers $\rightarrow$ Textile Company $\rightarrow$ Consumers

As depicted in the (Table 3) and (Table 4) above 52.03\% of sampled households were sold their cotton through local collectors and local collectors to wholesalers and after ginning wholesalers sold to Textile factories and finally after transformation of different clothes and clothing items textile company sold to consumers. Total quantity of cotton passed through this channel was $62.32 \%$, which was the largest quantity among the two channels cotton supply. 
Channel III: Farmers $\rightarrow$ Wholesalers $\rightarrow$ Textile Company $\rightarrow$ Consumers

Table 4: Amount of cotton sold to different types of traders.

\begin{tabular}{|c|c|c|c|c|c|c|}
\hline Amount Sold in 2016 & n & Minimum & Maximum & Sum & Mean & Std. Dev \\
\hline Local Collectors & 123 & 300 & 1100 & 64200 & 513.6 & 236.95 \\
\hline Wholesalers & 123 & 0 & 1000 & 29250 & 234 & 222.4 \\
\hline Retailer & 123 & 0 & 200 & 9690 & 77.52 & 67.2 \\
\hline
\end{tabular}

Source: Author Computation, 2016

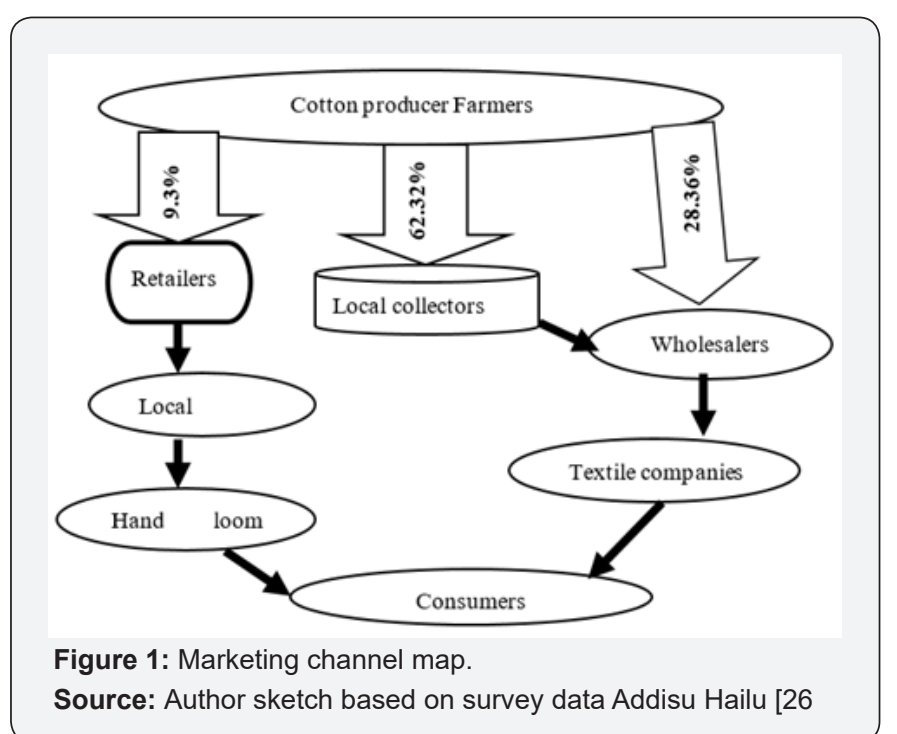

As described in the (Table 3) and (Table 4) above $24.39 \%$ of sampled households sold their cotton through this channel, which was the second large quantity of cotton supply, which was $28.36 \%$. In this channel sampled households sold their seed cotton to wholesalers and after ginning wholesalers sold to textile factories and finally after transformation textile factories sold to consumers (Figure 1).

\section{Cotton market structure-conduct-performance}

Cotton market structure: Market structure consists of the characteristics of the organization of a market which seems to influence strategically the nature of competition and pricing within the market [14]. In this study the structure of cotton marketing was characterized using the following indicators: market concentration, the degree of transparency (market information) and entry conditions (licensing, seasonality of business and policy barriers).

Market concentration: For this study only HerfindahlHirschman Index (HHI) was used because of the following benefits, according to Wisdom et al. [9], unlike the four-firm concentration ratio, the HHI reflects both the distribution of the market shares of the top four firms and the composition of the market outside the top four firms. It also gives proportionately greater weight to the market shares of the larger firms, in accordance with their relative importance in competitive interactions (Table 5).

Table 5: Cotton traders' Herfindahl-Hirschman Index (HHI) in Arbaminch zuria district.

\begin{tabular}{|c|c|c|c|c|c|}
\hline $\begin{array}{l}\text { Number of } \\
\text { Traders }\end{array}$ & $\begin{array}{l}\text { Amount Purchased } \\
\text { in } \mathbf{~ k g}\end{array}$ & $\begin{array}{l}\text { Total Quantity Pur- } \\
\text { chased in kg }\end{array}$ & $\%$ Share of Purchased & $\begin{array}{c}\text { \%Purchased Share } \\
\text { Squared }\end{array}$ & $\begin{array}{c}\text { \%Cumulative Pur- } \\
\text { chased }\end{array}$ \\
\hline & & & $M S i=\frac{V i}{\sum_{i=1}^{n} V i}$ & $M S_{i}^{2}$ & $H H I=\sum_{i=1}^{n} M S_{i}^{2}$ \\
\hline 1 & 1355000 & 1355000 & 0.735773241 & 0.541362262 & 0.553 \\
\hline 1 & 100000 & 100000 & 0.054300608 & 0.002948556 & \\
\hline 1 & 100000 & 100000 & 0.054300608 & 0.002948556 & \\
\hline 1 & 80000 & 80000 & 0.043440487 & 0.001887076 & \\
\hline 1 & 70000 & 70000 & 0.038010426 & 0.001444792 & \\
\hline 1 & 60000 & 60000 & 0.032580365 & 0.00106148 & \\
\hline 1 & 45000 & 45000 & 0.024435274 & 0.000597083 & \\
\hline 1 & 6000 & 6000 & 0.003258036 & $1.06 \mathrm{E}-05$ & \\
\hline 2 & 5000 & 10000 & 0.005430061 & $2.95 \mathrm{E}-05$ & \\
\hline 3 & 4000 & 12000 & 0.006516073 & $4.25 \mathrm{E}-05$ & \\
\hline 1 & 1000 & 1000 & 0.000543006 & $2.95 \mathrm{E}-07$ & \\
\hline 2 & 300 & 600 & 0.000325804 & $1.06 \mathrm{E}-07$ & \\
\hline 10 & 200 & 2000 & 0.001086012 & $1.18 \mathrm{E}-06$ & \\
\hline 26 & & 1841600 & & & \\
\hline
\end{tabular}

Source: Author Computation, 2016 
According to Naldi and Flamini [15], the HHI is obviously a positive figure. If the market shares are expressed as fractions of the whole market (that is., $0<\mathrm{Si} \leq 1$ ), then we have $0<\mathrm{HHI} \leq 1$. Instead, if the market shares are expressed as percentages (that is., $0<\mathrm{Si} \leq 100$ ), then we have $0<\mathrm{HHI} \leq 10000$. Since $\mathrm{HHI}=1$ indicates that market structure is monopoly, where a single firm takes all the market shares and $\mathrm{n}=1$ while, $\mathrm{HHI}=0$ indicates, where the market is uniformly distributed between the firms which is perfect competition.

The value of the HHI provides an indication of the level of concentration, with the maximum value corresponding to the case of the monopoly, and the minimum corresponding to perfect competition. Hence, the higher the value of the HHI, the higher the concentration of the market in the hands of a few companies. The U.S. Department of Justice provided guidelines for horizontal mergers first in 1985 and later revised them several times, till the latest version in 2010 .

For this study Herfindahl-Hirschman Indices was calculated by taking individual traders shares as fractions of the whole market to assess market concentration and its value was 0.553 , which shows that cotton marketing was highly concentrated in hands of few in Arbaminch Zuria district.

Degree of transparency: For this study degree of transparency was expressed in terms of the level of market information sharing among parallel cotton traders and cotton traders with cotton producing farmers.

Table 6: Cotton producer households' information sources and gathering system.

\begin{tabular}{|c|c|c|c|}
\hline Variables & Indicators & Frequency & Percentage \\
\hline \multirow{3}{*}{$\begin{array}{l}\text { Sources of Market } \\
\text { Information }\end{array}$} & $\begin{array}{l}\text { Neighboring } \\
\text { farmers }\end{array}$ & 81 & 65.85 \\
\hline & Traders & 14 & 11.39 \\
\hline & $\begin{array}{l}\text { From farmers } \\
\text { and traders }\end{array}$ & 28 & 22.76 \\
\hline \multirow{4}{*}{$\begin{array}{l}\text { System of Market } \\
\text { Information } \\
\text { Gathering }\end{array}$} & $\begin{array}{l}\text { Through } \\
\text { telephone }\end{array}$ & 19 & 15.45 \\
\hline & $\begin{array}{l}\text { Through physical } \\
\text { contact }\end{array}$ & 65 & 52.85 \\
\hline & $\begin{array}{c}\text { Through } \\
\text { telephone \& } \\
\text { news letters }\end{array}$ & 1 & 0.81 \\
\hline & $\begin{array}{c}\text { Telephone \& } \\
\text { physical contact }\end{array}$ & 38 & 30.89 \\
\hline \multirow{3}{*}{$\begin{array}{l}\text { Types of Information } \\
\text { Gathered }\end{array}$} & Producer price & 25 & 96.15 \\
\hline & Retailer price & 1 & 3.85 \\
\hline & Total & 26 & 100 \\
\hline \multirow{2}{*}{$\begin{array}{l}\text { Collaboration with } \\
\text { other Traders }\end{array}$} & Yes & 2 & 7.7 \\
\hline & No & 24 & 92.3 \\
\hline
\end{tabular}

Source: Author Computation, 2016

As depicted in (Table 6) above among sampled households $65.85 \%$ obtain market information from neighboring farmers, $22.76 \%$ obtained information from both farmers and traders and only $11.39 \%$ obtained market information from traders. This shows that market information (demand, supply, pricing and other information) sharing among cotton traders and cotton producing farmers was weak. Furthermore, about $52.85 \%$ of sampled households gather information through observing market places, which was tedious, expensive and time consuming method. It takes farmers extra labor and consumes more time.

As indicated in (Table 6) above $96.15 \%$ of traders share information about producer price and only $3.85 \%$ shared about retailer price. Furthermore, $92.3 \%$ traders not collaborate each other. This indicates that information sharing as well as collaboration among cotton traders in Arbaminch zuria district was weak.

Barriers to entry conditions: Barriers to entry to existing market can be defined in a variety of ways - any factors that increases the unit production cost of new entrants, or any impediments that imposes a cost on new entrants but not on the incumbents. In order to find out the factors that constrain the entry of new firms in the market, most studies have used data at industrial level as stated in Cubero [16]. Entry barriers for cotton marketing in Arbaminch zuria district were licensing requirements, seasonality of cotton supply and policy issues which are discussed in (Table 7) below.

Table 7: Market entry barriers.

\begin{tabular}{|c|c|c|c|}
\hline Variables & Indicators & Frequency & Percentage \\
\hline \multirow{2}{*}{$\begin{array}{c}\text { Do you have License for } \\
\text { Cotton Marketing? }\end{array}$} & Yes & 6 & 23.1 \\
\cline { 2 - 4 } & No & 20 & 76.9 \\
\hline \multirow{4}{*}{$\begin{array}{c}\text { Duration of Undertaking } \\
\text { Business }\end{array}$} & Year round & 3 & 11.5 \\
\cline { 2 - 4 } & Two months & 23 & 88.5 \\
\cline { 2 - 4 } & Total & 26 & 100 \\
\hline \multirow{3}{*}{$\begin{array}{c}\text { Aware of Cotton Marketing } \\
\text { Related Government Policy }\end{array}$} & Yes & 1 & 3.8 \\
\cline { 2 - 4 } & No & 25 & 96.2 \\
\cline { 2 - 4 } & Total & 26 & 100 \\
\hline
\end{tabular}

Source: Author Computation, 2016

As depicted in (Table 7) above $76.9 \%$ of sampled traders did not have cotton marketing license. This indicates that licensing requirement did not impede new entrant for cotton marketing. Furthermore, $88.5 \%$ of traders undertake, cotton marketing for only two months (October to December), which was period of high cotton supply, but those small quantity purchasers undertook the business throughout the year, which were only $11.5 \%$ among surveyed cotton traders. This indicates that seasonality of cotton marketing hinders new entrant to the business. Also $96.2 \%$ of sampled traders did not have awareness about cotton related government policies. This indicates that having or not having awareness about cotton marketing, government policies could not affect entry to cotton marketing in Arbaminch zuria district negatively.

From all the above observed situations which are large $\mathrm{HHI}$, information imperfection and presence of some barriers to entry let cotton market structure to be classifies as oligopoly market 
structure. Hence, cotton market in Arbaminch zuria district deviated from competitive market norms.

Cotton market conduct: Market conduct refers to the patterns of behavior that traders and other market participants adopt to affect or adjust to the markets in which they sell or buy. These include price setting behavior, and buying and selling practices, weighing and trust among seller and buyers.

As indicated in (Table 8) above sampled cotton producing farmers reported that price for cotton was determined by traders.
However,100\% sampled traders reported that they encountered problems in cotton marketing and $92.3 \%$ of traders reported that cotton producer farmers supply quality deteriorated cotton to the market. Field observation indicates that there was cheat among cotton producer farmers and traders. Farmers adulterate cotton with stones and soil and bring watered cotton to market to weigh high. Traders also cheat farmers when they weigh cotton. Furthermore, $100 \%$ of sampled cotton producer households reported absence of grading in cotton as a result they receive the same price whether they brought quality cotton or not.

Table 8: Cotton marketing conduct elements.

\begin{tabular}{|c|c|c|c|}
\hline Variables & Indicators & Frequency & percent \\
\hline Who Set Cotton Price & Traders & 123 & 100 \\
\hline Do You Grade Your Cotton & No & 123 & 100 \\
\hline Encounter Problems in Cotton Marketing & Yes & 26 & 100 \\
\hline \multirow{3}{*}{ If yes, What are the Problems } & Quality deterioration & 24 & 92.3 \\
\cline { 2 - 4 } & Quality deterioration and supply shortage & 2 & 7.7 \\
\cline { 2 - 4 } & Total & 26 & 1000 \\
\hline
\end{tabular}

\section{Source: Author Computation, 2016}

Cotton market performance: Cotton marketing performance was measured in marketing margin and market efficiency. According to Adegeye and Dittoh [17], marketing margin refers to the difference in price paid to the first seller and that paid by the final buyer. According to Jema [18], marketing margin is the whole price in excess of farm price. But, for cotton marketing output of marketing was proxied by net profit from cotton marketing activities and input of cotton marketing was proxied by cost of cotton marketing and which were calculated as

Table 9: Cotton marketing margin and marketing costs and profit (birr/100kg).

\begin{tabular}{|c|c|c|c|c|c|c|}
\hline Marketing Actors & Selling Price & $\begin{array}{l}\text { Total Marketing/ } \\
\text { Production Costs }\end{array}$ & Gross Profit & $\%$ TGMM & $\%$ Profit Share & Marketing Efficiency (\%) \\
\hline Producer/Farmers & 1000 & 637.69 & 362.31 & 18.38 & 20.59 & 56.81 \\
\hline Local Collectors & 1150 & 1096 & 54 & 2.76 & 3.07 & 56.25 \\
\hline Retailers & 1350 & 1150 & 200 & 3.68 & 11.36 & 133.33 \\
\hline Wholesalers & 2515 & 1575.5 & 939.5 & 21.41 & 53.38 & 220.8 \\
\hline Textile Company & 5440 & 5236 & 204 & 53.77 & 11.6 & 12.47 \\
\hline Total & & & & 100 & 100 & \\
\hline
\end{tabular}

Source: Author Computation, 2016

As presented in (Table 9) total gross margin added to cotton price when it passes through the marketing system was $81.62 \%$. The farm retail price which were accrued to each category of participants in return for the marketing services other than farmers in percentage terms of local collectors, wholesalers, retailers and textile company were, $2.76 \%, 21.41 \%, 3.68 \%$ and $53.77 \%$, respectively.

The farmer's share of the price to end user was $18.38 \%$. Local collectors receive smaller percentage of profit $(3.07 \%)$. However, wholesalers received relatively larger percentage of price $(53.38 \%)$ and retailers were received $11.36 \%$ and Textile Company received $11.6 \%$, respectively.

According to Osondu et al. [19], marketing efficiency ratio of follows: $\quad \mathrm{GMMLC}=2.76 \%, \quad \mathrm{GMMRR}=3.68 \%, \quad \mathrm{GMMWS}=21.41 \%$, GMMTC $=53.77 \%$, GMMPP $=18.38 \%$

Where;

GMMLC was gross market margin of local collectors, GMMRR was gross market margin of retailers, GMMWS was gross market margin of wholesalers, GMMTC was gross market margin of textile company and GMMPP was gross market margin of producers. 


\section{Econometric results}

Multiple linear regressions model analysis was used to identify factors affecting quantity cotton supply to market. Before fitting multiple linear regressions, the hypothesized explanatory variables were checked for existence of multicollinearity, heteroscedasticity and endogeneity problem.

Test of multicollinearity: All VIF values are less than 10 . This indicates absence of serious multicollinearity problem among independent variables. If there is presence of multicollinearity between independent variables, it is impossible to separate the effect of each parameter estimate in the dependent variables.

Test of heteroscedasticity: Since there is heteroscedasticity problem in the data set, the parameter estimates of the coefficients of the independent variables cannot be BLUE. Therefore, to overcome the problem, Robust OLS analysis with heteroscedasticity consistent covariance matrix was estimated.

Test of endogeneity: When a variable is endogenous, it will be correlated with the disturbance term, hence violating the OLS assumptions and making our OLS estimates biased. Testing for endogeneity of productivity of cotton were carried out in the model using both Hausman test and Durbin-WuHausman (DWH) test and endogeneity problem were not found in productivity variable in cotton. Hausman test result indicated that, the predicted productivity was statistically insignificant with $(\mathrm{p}=0.1203)$ for cotton.
In the first stage of 2SLS method, regressions was run and analyzed using eleven explanatory variables including instrumental variable and the result shows that, size of land allocated to cotton, improved seed, extension contact and current year cotton price were affects positively and significantly the productivity of cotton whereas cotton farming experience affects negatively and significantly the productivity of cotton. Size of land allocated to cotton production was used as instruments for productivity. In second stage of 2SLS from hypothesized eleven explanatory variables six variables productivity of cotton, cotton farming experience, distance from nearest market, use of improved seed, frequency of extension contact and current year cotton price significantly influence quantity of cotton supply to market. Therefore, application of ordinary least square (OLS) method of data analysis was found to be appropriate for the study.

Factors affecting farm household level cotton supply to market: Access to credit was omitted from the model because all interviewed cotton farming household's response was the same. Also access to market information was omitted from the model because descriptive statistic result shows that absence of market information variation among sampled cotton producer farmers was insignificant. Dependent variable (Quantity of cotton supplied to market) was transformed to natural logarithmic form. The explanation on the effect of the significant explanatory variables is discussed below.

Table 10: Factors affecting household level cotton supply to market.

\begin{tabular}{|c|c|c|c|}
\hline Quantity of Cotton Supplied to Market (In) & Coefficient & Std. Err. & 0.833 \\
\hline Sex of household head & 0.012 & 0.004 & 0.014 \\
\hline Cotton farming experience & $-0.011^{* * *}$ & 0.076 & -2.75 \\
\hline Education level of households & -0.045 & 0.081 & -0.592 \\
\hline Land allocated to cotton in hectare & $0.268^{* * *}$ & 0.037 & 3.308 \\
\hline Number of ploughing aged oxen Authored & -0.03 & 0.109 & -0.81 \\
\hline Use of improved seed & $0.810^{* * *}$ & 0.018 & 7.431 \\
\hline Active labor force engaged in cotton production & 0.003 & 0.008 & 0.167 \\
\hline Extension contact & $0.019^{* *}$ & 0.008 & -2.375 \\
\hline Distance to nearest market & $-0.018^{* *}$ & 0.021 & 1.095 \\
\hline Lagged year price of cotton per kg & 0.023 & 0.102 & 3.245 \\
\hline Current year cotton price & $0.331^{* * *}$ & 0.081 & -0.096 \\
\hline Productivity of cotton per hectare & 0.103 & 1.366 \\
\hline
\end{tabular}

Dependent variable is quantity of cotton supply to market in 2016 , Number of observations $=123, F(12,110)$, Adj R-squared=0.95

Source: Author Computation, 2016

Note: ${ }^{* * *},{ }^{* *},{ }^{*}$, significance at $1 \%, 5 \%$, and $10 \%$, respectively.

Cotton farming experience: This is continuous variable and hypothesized to affect cotton supplied to market positively. In contrast cotton farming experience affected cotton supplied to market negatively at $1 \%$ level of significance. Existing tradition of cotton farming, in Arbaminch zuria district is losing its originality due to obstacles faced by substituting other cash crops like banana and food crops like teff and maize as indicated in Merima and
Gezahegn [21]. Similarly, field observation shows that farmers with long farming experience were cultivating banana as cash crops rather than cotton. Also, they did not cultivate cotton on irrigated land, but they cultivate cotton on marginalized and nonirrigated plots of land. As regression result indicated in (Table 10) keeping other factors constant, an increase in farming experience by one year decreases cotton supply by $1.1 \%$. 
Land allocated to cotton in hectare: This is continuous variable and hypothesized to affect cotton supplied to market positively. As hypothesized earlier, the variable is positively related to amount of cotton supplied to market at $1 \%$ level of significance. As regression result shows in (Table 3) keeping other factors constant, an increase in one hectare of land allocation to cotton cultivation increases cotton supply by $26.8 \%$. The result coincides with the study of Bosena et al. [3], Beza [22] and Addisu [23], where increase in land increased cotton, food grain, maize and faba bean and onion volume supplied to market, respectively.

Use of improved seed: This is dummy variable and hypothesized to affect cotton supplied to market positively. As hypothesized earlier, the variable is positively related to amount of cotton supplied to market at $1 \%$ level of significance. As indicated in regression result keeping other factors constant, use of improved cotton varieties increases cotton supply by $81 \%$. The result of study was in line with previous study conducted by Alemayehu [24], where use of new ginger variety increased amount of ginger supplied.

Current year cotton price: This is continuous variable and expected to affect cotton supplied to market positively. As hypothesized, the variable is positively affected amount of cotton supplied to market at $1 \%$ level of significance. As regression result indicates that keeping other factors constant, increase in one birr per kilo gram of cotton increase cotton supply by $33.1 \%$. The study result was in consistent with previous study conducted by Alemnew [25], Mebrat [26], and Wendmagegn [27], where increase in one birr increased red pepper, tomato and coffee quantity supplied to market, respectively.

Extension contact: This is continuous variable and expected to affect quantity of cotton supply positively. As expected, number of extensions contact positively affected the amount of cotton supplied to market at $5 \%$ level of significance. As regression result indicates keeping other factors constant, an increase in extension contact per production year increases cotton supply by $1.9 \%$. This result was in confirmation with the study conducted by Ayelech [28], Mohammed [29], Wendmagegn [27] and Bizualem et al. [30], where increase in unit of contact with extension increased mango, teff and wheat and coffee quantity supplied to market, respectively.

Distance to nearest market: This is continuous variable and expected to affect quantity of cotton supply to market negatively. As hypothesized, the variable is negatively related to amount of cotton supplied to market at $5 \%$ level of significance. Thus, regression result shows that keeping other factors constant, an increase in one kilo meter far away from nearest market decreases cotton supply to market by $1.8 \%$. The result of study was in consistent with previous study conducted by Mohammed [29], Mebrat [26], Wendmagegn [27], Yimer [31], where increase in 1-kilometer, decreased coffee, tomato, and fruit quantity supplied to market, respectively.

\section{Conclusion and Recommendation}

\section{Conclusion}

Structure of cotton marketing was characterized using: market concentration, the degree of transparency (market information sharing) and entry conditions (licensing, seasonality of business and policy barriers). To measure market concentration HHI was used and its value was 0.553 , which shows that cotton marketing was highly concentrated on hands of few in Arbaminch zuria district. Among sampled households only $11.39 \%$ gather market information from traders and $22.76 \%$ gathers information from both farmers and traders. This shows that market information (demand, supply, pricing and other information) sharing among cotton traders and cotton producing farmers were weak. Among total sampled traders $96.15 \%$ share information about producer price only. Furthermore, $92.3 \%$ of traders not collaborate with each other. This indicates that information sharing as well as collaboration among cotton traders in Arbaminch zuria district was weak. Thus, large HHI, information imperfection and presence of some barriers to entry let cotton market structure to be classifies as oligopoly market structure. Hence, cotton market in Arbaminch zuria district deviated from competitive market norms.

Market conduct refers to the patterns of behavior that traders and other market participants adopt to affect or adjust to the markets in which they sell or buy. These include price setting behavior, and buying and selling practices, weighing and trust among seller and buyers. Cotton producing farmers reported that price for cotton was determined by traders while $100 \%$ sampled traders reported that they encountered problems in cotton marketing and $92.3 \%$ of sampled traders reported that cotton producer farmers supply quality deteriorated cotton to the market. Researcher field observation indicated that there was cheating among cotton producer farmers and traders. Farmers adulterate cotton with stones and soil and bring watered cotton to market to weigh high, while traders cheat farmers when they weigh cotton. These acts indicate that cotton marketing conduct in Arbaminch zuria district was not well enough.

Cotton marketing performance was measured in marketing margin and market efficiency. Total gross margin added to cotton price when it passes through the marketing system was $81.62 \%$. The farmer's share of the price to end user was $20.59 \%$. Local collectors receive smaller percentage of profit (3.07\%). However, wholesalers received relatively larger percentage of profit (53.38\%). Among Arbaminch zuria district cotton marketing participants' only wholesalers and retailers cotton marketing show presence of excess profit, which was $220.8 \%$ and $133.33 \%$ respectively. However, smallholder cotton producer farmers, local collectors and Textile Company were considered inefficient because their market efficiency was below $100 \%$. Among twelve variables included in multiple linear regression, six variables, namely; cotton farming experience, land allocated to cotton in 
hectare, use of improved seed, and current year cotton price were found to be significant at $1 \%$ significance level. Also, number of extensions contact and distance to nearest market were found to be significant at $5 \%$ significance level.

\section{Recommendation}

Based on result of this study, the following recommendations were made.

a. Agricultural offices, universities and research institutions should pay attention for provision of improved, high yielding and diseases resistant cotton varieties

b. Agricultural offices should create awareness among farmers to allocate appropriate land for cotton and to produce cotton in irrigation as of other cash crops.

c. National and regional governments may pay attention for strengthen the existing textile factories to he help them to absorb quantities of cotton produced by cotton producer farmers.

d. District, Zonal and Regional Agriculture and natural resource offices, trade and industry offices should work for the regulation and implementation of cotton price tariffs and production related polices.

e. District and Zonal Cooperative offices and trade office should frequently monitor cotton marketing system of cotton producing districts and take corrective measures as early as possible because field observation and interview with chain actors shows that there was cheat between cotton producer farmers and traders.

f. Zonal and District Agriculture and Natural resource offices should strengthen provision of sustainable and knowledgebased extension service because increase in one extension contact increases quantity cotton supplied.

\section{References}

1. EDRI (Ethiopian Development Research Institute) (2015) Institutional Assessment of the Cotton and Sugarcane Commodities in Ethiopia: The climate change perspective. Addis Ababa, Ethiopia.

2. EIA (Ethiopian Investment Agency) (2012) Investment Opportunity Profile for Cotton Production and Ginning in Ethiopia. Addis Ababa, Ethiopia.

3. Bosena Tegegne, Fikadu Bekabil, Berhanu G, Dirk H (2011) Factors Affecting Cotton Supply at the Farm Level in Metema District of Ethiopia. Journal of Agriculture Biotechnology \& Ecology 4(1): 41-51.

4. MoANR (Ministry of Agriculture and Natural Resource) (2004) Market Oriented Development Master Plan for Cotton in Ethiopia. Addis Ababa, Ethiopia.

5. Bosena Tegegne (2008) Cotton market chain analysis: the case of Metema Woreda, North Gondar Zone, Amhara National Regional State. MSc Thesis, Haramaya University, Haramaya, Ethiopia. p. 110.

6. PAN Ethiopia (Pest Action Network) (2014) Cotton farmers do better with IPM in Arbaminch, Ethiopia. Research report submitted to Alliance for Food Sovereignty in Africa.

7. Yamane Taro (1967) Statistics: An Introductory Analysis, $\left(2^{\text {nd }}\right.$ edn), New York: Harper and Row.
8. Meryem Kuru (2013) Analysis of Cow Milk Market Chain: The case of Sululta District, Oromia Special Zone. MSc Thesis, Haramaya University, Haramaya, Ethiopia.

9. Wisdom Madede Nzima, Joseph Dzanja, Bonnet Kamwan (2014) Structure, Conduct and Performance of Groundnuts Markets in Northern and Central Malawi: Case Studies of Mzimba and Kasungu Districts. International Journal of Business and Social Science 5(6): 130-139.

10. Mendoza (1995) A primer on marketing channels and margins.

11. Osougwu (2002) Economic Analysis of Rice Marketing Margin among participants in the marketing channel of rice in Adani in Uzo Uwani Local Government Area.

12. Gujarati (2003) Essentials of econometrics.

13. Islam MS, Miah TH, Haque MM (2001) Marketing System of Marine Fish in Bangladesh: An Empirical Study. Bangladesh J Agric Econs 1(2): 127142.

14. Harriss B (1993) Measuring Agricultural Performance in Agricultural and Food Marketing in Developing Countries. Trowbridge Wittshire: Redwood Book Limited.

15. Naldi M, Flamini M (2014) The CR4 index and the interval estimation of the Herfindah Hirschmann index: An empirical comparison. SSRN, p. 11.

16. Cubero Ana Rosado (2010) Barriers to competition: the evolution of the debate, London Peckering and Chatto. p. 1-2.

17. Adegeye A, Dittoh J (1985) Essentials of Agricultural Economic. Impact Publisher, Ibadan, Nigeria Ltd. pp. 164-177.

18. Jema (2008) Economic efficiency and marketing performance of vegetable production in the eastern and central parts of Ethiopia.

19. Osondu K, Nwadike FC, Ijioma JC, Udah SC, Ugboaja CI (2014) Marketing Performance of Salad Vegetables: The Case of Cabbage Marketing in Abia State, Nigeria. International Journal of Agricultural Science, Research and Technology in Extension and Education Systems 4(3): 151-162.

20. Scarborough V, Kydd J (1992) Economic Analysis of Agricultural Markets. A Manual of Marketing Series 5, Chatham, UK: Natural Resource Institute.

21. Merima Abudullahi, Gezahegn Ayele (2008) Agri-Chain Analysis of Cotton Sub-Sector in Ethiopia. Research Report Submitted to Ethiopian Development Research Institute Addis Abeba, Ethiopia.

22. Beza Erko (2014) Maize and Faba Bean Value Chains: The Case of BakoTibe and Gobu Seyo Districts in Central Western Ethiopia. MSc Thesis, Haramaya University, Haramaya, Ethiopia.

23. Addisu Hailu (2016) Value Chain Analysis of Vegetables: The Case of Ejere District, West Shoa Zone, Oromia National Regional State of Ethiopia. Haramaya University, Haramaya, Ethiopia.

24. Alemayehu Asale (2012) Analysis of Production and Market Channel of Ginger: The Case of Boloso Bombe and Kindo Koisha Woredas of Wolaita Zone. Haramaya University, Haramaya, Ethiopia.

25. Alemnew Abay (2010) Market Chain Analysis of Red Pepper: The Case of Bure Woreda, West Gojjam Zone, Amhara National Regional State, Ethiopia. MSc Thesis, Haramaya University, Haramaya, Ethiopia.

26. Mebrat Tola (2014) Tomato Value Chain Analysis in the Central Rift Valley: The Case of Dugda Woreda, East Shoa Zone, Oromia National Regional State, Ethiopia. MSc Thesis, Haramaya University, Haramaya, Ethiopia.

27. Wendmagegn Belete (2014) Market Chain Analysis of Coffee in Dale District of Southern Ethiopia. MSc Thesis, Haramaya University, Haramaya, Ethiopia. 
28. Ayelech Tadesse (2011) Market Chain Analysis of Fruits for Gomma Woreda, Jimma Zone, Oromia Regional State. MSc Thesis, Haramaya University, Haramaya, Ethiopia.

29. Mohammed D, David Asamoah, Felicity Asiedu-Appiah (2011) Cocoa Value Chain-Implication for the Smallholder Farmer in Ghana. pp. 1041-1049.
30. Bizualem Assefa, Degye Goshu, Zekarias Shumeta (2015) Analysis of marketed Surplus of Coffee by Smallholder Farmers in Jimma Zone, Ethiopia. Journal of Biology Agriculture and Healthcare 5(5): 242-251.

31. Yimer Ayalew (2015) Factors Affecting Fruit Supply in The Market: The Case of Habru Woerda, North Wollo, Ethiopia Regional State, Ethiopia. Journal of Marketing and consumer Research 7: 35-44.

\section{Your next submission with Juniper Publishers will reach you the below assets}

- Quality Editorial service

- Swift Peer Review

- Reprints availability

- E-prints Service

- Manuscript Podcast for convenient understanding

- Global attainment for your research

- Manuscript accessibility in different formats

(Pdf, E-pub, Full Text, Audio)

- Unceasing customer service

Track the below URL for one-step submission https://juniperpublishers.com/online-submission.php 